\title{
High prescription of antimicrobials in a rural district hospital in India
}

\author{
Gerardo ALVAREZ-URIA, Seeba ZACHARIAH, Dixon THOMAS \\ Received (first version): 7-Dec-2013 \\ Accepted: 9-May-2014
}

\begin{abstract}
${ }^{*}$
Background: The World Health Organization (WHO) recommends surveillance of antibiotic use as part of the strategy to fight against antimicrobial resistance. However, there is little information about the antibiotic consumption in developing countries, especially in rural areas.

Objective: The objective of this study was to describe the antimicrobial consumption in a rural hospital in India Methods: The study was performed in a district hospital situated in Anantapur, Andhra Pradesh. In accordance with WHO recommendations, we used the defined daily dose (DDD) methodology to measure the antibiotic use during one year (from 1st August 2011 to 1st August 2012). The antibiotic use was measured using DDDs/100 admissions and DDDs/100 patient-days for inpatients, and DDDs/100 visits for outpatients.

Results: During the study period, there were 15,735 admissions and 250,611 outpatient visits. Antibiotics were prescribed for $86 \%$ of inpatients and $12.5 \%$ of outpatients. Outpatient prescriptions accounted for $2 / 3$ of the overall antibiotic consumption. For inpatients, the total antibiotic use was 222 DDDs/ 100 patient-days, 693 DDDs/ 100 admissions and the mean number of antibiotics prescribed was 1.8. For outpatients, the total antibiotic use was 86 DDDs/ 100 outpatient visits and the mean number of antibiotics prescribed was 1.2. The most common antibiotics prescribed were aminopenicillins and 3rd generation cephalosporins for inpatients, and tetracyclines and quinolones for outpatients. In a sample of patients with diarrhoea or upper respiratory tract infections (URTI), the proportion of patients who received antibiotics was $84 \%$ (95\% confidence interval [Cl], 67-93) and 52\% (95\% $\mathrm{Cl}, 43-62)$, respectively.

Conclusion: In this rural setting, the use of antimicrobials was extremely high, even in conditions with a predominantly viral aetiology such as diarrhoea or URTI.
\end{abstract}

Keywords: Anti-Bacterial Agents; Drug Resistance, Bacterial; Drug Utilization; Inappropriate Prescribing; Rural Health; India

*Gerardo ALVAREZ-URIA. Fundación Vicente FerrerRural Development Trust Hospital, Bathalapalli (India). gerardouria@gmail.com

Seeba ZACHARIAH. Department of Pharmacy Practice, Raghavendra Institute of Pharmaceutical Education \& Research. Anantapur (India). seebadixon@gmail.com Dixon THOMAS. Department of Pharmacy Practice, Nirmala College of Pharmacy, Ernakulam (India). dixon.thomas@gmail.com

\section{INTRODUCTION}

While antimicrobial resistance is a major concern worldwide, it is especially important for developing countries because of the high mortality associated with common bacterial infections in resource-limited settings. ${ }^{1}$ Antibiotic pressure is the single most important factor for the selection of resistant bacteria and the appearance of new mechanisms of resistance $^{2}$, but studies describing antibiotic consumption in developing countries are scarce.

In India, antibiotic spending has increased by about $40 \%$ between 2005 and 2009. ${ }^{2}$ Although more than two thirds of the Indian population are rural residents, little is known about the consumption patterns of antibiotics in rural India because previous studies have been performed in urban areas or tertiary hospitals. ${ }^{2-5}$ The aim of this study was to describe the consumption of antibiotics in a district hospital situated in a rural area of India. In addition, we also investigated the proportion of patients who received antibiotics in a sample of cases diagnosed with diarrhoea or upper respiratory tract infection (URTI), because these conditions are predominantly of viral aetiology.

\section{METHODS}

\section{Setting}

The study was performed at the Rural Development Trust General Hospital, a non-profit 220-bed hospital in Bathalapalli, Andhra Pradesh, India. Bathalapalli is a village of 9810 habitants located in the district of Anantapur. In Anantapur, $72 \%$ of the population lives in rural areas and $36 \%$ are illiterate. ${ }^{7}$

The hospital has an average occupancy rate of $90 \%$ and a small 7-bed Intensive Care Unit. The hospital belongs to a non-governmental organization called Fundación Vicente Ferrer - Rural Development Trust, which provides free consultation and medicines at reduced prices to people of low socioeconomic status. The hospital has a Microbiology Department, which provides antimicrobial susceptibilities of bacterial infections, but there is not a stewardship programme to control the use of antibiotics.

\section{Study design}

We collected data on antibiotic prescriptions from the Hospital Database during one year (from $1^{\text {st }}$ August 2011 to $1^{\text {st }}$ August 2012) for avoiding seasonal variation of antibiotic use. 


\begin{tabular}{|c|c|c|c|c|}
\hline & Total & Medicine & O\&G & Surgery \\
\hline \multicolumn{5}{|l|}{ Inpatients } \\
\hline Admissions (N) & 15735 & 2901 & 9575 & 3259 \\
\hline Any antibiotic (\%) & 86 & 62.9 & 92.2 & 88.4 \\
\hline $\mathrm{N}$ of antibiotics (mean) & 1.81 & 2.2 & 1.67 & 1.99 \\
\hline Days of admission (mean) & 3.1 & 4.3 & 2.5 & 3.9 \\
\hline DDDs/100 patient-days & 221.9 & 153.2 & 294.8 & 150.8 \\
\hline DDDs/100 admissions & 692.5 & 652.3 & 739.7 & 589.5 \\
\hline \multicolumn{5}{|l|}{ Outpatients } \\
\hline Visits $(\mathrm{N})$ & 250611 & 120241 & 88264 & 42106 \\
\hline Any antibiotic (\%) & 12.5 & 14.91 & 8.98 & 13.04 \\
\hline $\mathrm{N}$ of antibiotics (mean) & 1.21 & 1.18 & 1.24 & 1.26 \\
\hline DDDs/100 visits & 86.16 & 104.68 & 58.47 & 91.31 \\
\hline
\end{tabular}

Following recommendations from the World Health Organization (WHO), the measurement of antibiotic consumption was performed using the Anatomic Therapeutic Classification (ATC) index with the defined daily dose (DDD) methodology. ${ }^{8}$ The ATC/DDD methodology is a tool for drug utilization research in order to improve quality of drug use by allowing comparison of drug consumption statistics at international or other levels. ATC is a code to classify drugs according to their therapeutic and pharmacological use. The DDD is the assumed average maintenance dose per day for a drug used for its main indication in adults. ${ }^{8}$ The DDD provides a fixed unit of measurement independent of price and dosage form (e.g. tablet strength) enabling researchers to assess trends in drug consumption and to perform comparisons between population. ${ }^{8}$ As the DDD methodology is not adequate for studying drug use in children, paediatric patients were excluded from the study.

For inpatients, we used two parameters to measure the antibiotic consumption, the DDDs/100 admissions and the DDDs/100 patient-days, being patient-days the total number of days of admission. For outpatient, we used the DDDs/100 visits to the outpatient clinics.

For studying the inappropriate use of antibiotics in a sample of outpatients, we studied the prescriptions of patients who were diagnosed with diarrhoea or URTI from March $1^{\text {st }} 2012$ to March $14^{\text {th }} 2012$.

The study was approved by the Hospital Ethical Committee. Statistical analysis was performed using Stata Statistical Software (Stata Corporation. Release 11. College Station, Texas, USA).

\section{RESULTS}

During the period of the study, the total number of antibiotic DDDs prescribed was 324,$882 ; 108,962$ (33.5\%) DDDs in inpatients and 215,920 (66.5\%) DDDs in outpatients. Description of antibiotic consumption by DDDs/ 100 patient-days, DDDs/ 100 admissions, DDDs/ 100 outpatient visits, and the proportion (percentage) of patients who received any antibiotic is presented in Table 1.

Overall, $86 \%$ of inpatients received antibiotics. Surgical specialities had higher proportion of inpatients on antibiotics than Medicine. However, for those patients who received antibiotics, the number of antibiotics prescribed was higher in the Medicine Department. The number of DDDs/100 patient-days in inpatients was 222. The highest number of DDDs/100 patient-days was observed in the Department of Obstetrics and Gynaecology (O\&G).

Overall, $12.5 \%$ of outpatients received antibiotics and the number of DDDs/100 outpatient visits was 86. The highest prescription of antibiotics was observed in the Medicine Department, followed by Surgery and O\&G.

Through patient exit interviews, we identified 31 patients diagnosed with diarrhoea and 107 patients diagnosed with URTI. The proportion of patients who received antibiotics was $83.9 \%$ (Wilson 95\% confidence interval, 67.3-92.9) for diarrhoea and $52.3 \%$ (Wilson $95 \%$ confidence interval, 43-61.6) for URTI.

Table 2 describes the consumption of antibiotics that accounted for the $90 \%$ of the prescriptions (drug utilization 90\%) overall and by hospital departments.

\begin{tabular}{|c|c|c|c|c|c|c|c|c|c|c|c|c|}
\hline \multirow{2}{*}{ antibiotic group } & \multicolumn{4}{|c|}{ DDDs/100 patient-days (IP) } & \multicolumn{4}{|c|}{ DDDs/100 admissions (IP) } & \multicolumn{4}{|c|}{ DDDs/100 outpatient visits } \\
\hline & Total & Med & O\&G & Surg & Total & Med & O\&G & Surg & Total & Med & O\&G & Surg \\
\hline Aminopenicillins & 171.73 & 11.07 & 313.43 & 60.32 & 536.02 & 47.13 & 786.33 & 235.79 & 18.03 & 18.05 & 8.6 & 37.75 \\
\hline $\begin{array}{l}\text { Aminopenicillin \& } \\
\text { enzyme inhibitor }\end{array}$ & 19.95 & 39.6 & 3.55 & 31.82 & 62.27 & 168.62 & 8.91 & 124.36 & 20.23 & 25.27 & 5.17 & 37.41 \\
\hline $\begin{array}{l}3^{\text {rd }} \text { generation } \\
\text { cephalosporins }\end{array}$ & 76.94 & 47.15 & 117.54 & 29.28 & 240.16 & 200.78 & 294.89 & 114.44 & 17.43 & 20.45 & 15.23 & 13.4 \\
\hline Lincosamides & 1.41 & 2.17 & 0.23 & 2.91 & 4.41 & 9.23 & 0.57 & 11.38 & 0.05 & 0.03 & 0.03 & 0.13 \\
\hline Tetracyclines & 17.06 & 59.75 & 2.84 & 2.48 & 53.26 & 254.46 & 7.12 & 9.7 & 47.28 & 67.1 & 29.14 & 28.7 \\
\hline Imidazoles & 23.61 & 22.74 & 13.94 & 42.67 & 73.68 & 96.86 & 34.98 & 166.78 & 16.84 & 15.14 & 15.79 & 23.87 \\
\hline Macrolides & 4.99 & 7.54 & 5.43 & 1.7 & 15.59 & 32.13 & 13.62 & 6.66 & 7.36 & 9 & 7.06 & 3.32 \\
\hline Quinolones & 11.57 & 30.42 & 1.66 & 12 & 36.13 & 129.54 & 4.15 & 46.91 & 25.24 & 31.26 & 19.57 & 19.92 \\
\hline Co-trimoxazole & 2.04 & 2.71 & 0.56 & 4.18 & 6.36 & 11.53 & 1.4 & 16.33 & 1.01 & 1.06 & 0.55 & 1.84 \\
\hline Aminoglycosides & 9.44 & 9.55 & 4.09 & 19.41 & 29.46 & 40.67 & 10.26 & 75.89 & 0.3 & 0.31 & 0.09 & 0.69 \\
\hline
\end{tabular}


In patients admitted to O\&G or Surgery, the most commonly prescribed antibiotics were aminopenicillins, followed by $3^{\text {rd }}$ generation cephalosporins and imidazoles. In patients admitted in Medicine, the most commonly prescribed antibiotics were tetracyclines, $3^{\text {rd }}$ generation cephalosporins, aminopenicillin with enzyme inhibitor (amoxicillin/clavulanic acid) and quinolones.

In outpatients, the most commonly prescribed antibiotics were tetracyclines, quinolones, aminopenicillins with enzyme inhibitor, aminopenicillins, $3^{\text {rd }}$ generation cephalosporins and imidazoles. Antibiotics effective against anaerobes such as imidazoles and aminopenicillins with enzyme inhibitor were more commonly prescribed in the Surgical Department.

\section{DISCUSSION}

To our knowledge, this is one of the first studies to investigate the prescribing of antibiotics in a rural hospital in India using the methodology recommended by the WHO.

Among inpatients, the number of DDDs/ 100 patient-days was 222 , which is four times higher than the ones reported in Europe and China. ${ }^{9,10}$ In a study from Ujjain, MP India, the proportion of admitted patients who received any antibiotic was $78-82 \%$, which is similar to the one found in our hospital. $^{11}$

A comparison of our outpatient antibiotic use with western countries is difficult because other studies have utilized DDDs/1000 inhabitants daily to measure outpatient antibiotic consumption. ${ }^{12,13}$ The proportion of patients with diarrhoea or URTI who received antibiotics was higher than previously reported in other sites. ${ }^{14-16}$ However, the proportion of outpatients who received any antibiotic was similar to the ones described in other urban Indian sites. $^{2-5}$ In a study investigating the antimicrobial prescription in outpatients with symptoms of acute infection at four sites in India, the proportion of patients from rural areas who received antibiotics was $71.7 \%(95 \% \mathrm{Cl}, 68.6-74.8){ }^{6}$

Previous studies have shown that antibiotic exposure has an important role in the emergence of antimicrobial resistance in the population. ${ }^{\uparrow, 18}$ The high consumption of antibiotics described in the present study could have an important impact on the appearance of antimicrobial resistance in the community. In fact, we have recently described high rates of methicillin resistant Staphylococcus aureus and third-generation cephalosporin resistant Gram negative bacteria in our setting. ${ }^{19,20}$

Western countries have responded to the problem of antimicrobial overuse by implementing institutional programmes to optimize clinical outcomes while reducing the risks associated with antibiotic overuse, including toxicity and the emergence of resistance. ${ }^{9,21}$ The combination of antimicrobial stewardship and infection control programmes have demonstrated to limit the emergence and transmission of resistant bacteria and to reduce the direct and indirect health-care costs associated with the misuse of antimicrobials. ${ }^{21}$ Ideally, these programmes should include a clinical microbiologist, an infectious disease physician, a clinical pharmacist and an infection control professional. The strategies to improve the use of antimicrobial are multiple: direct interaction and feedback to the prescribers; formulary restriction and pre-authorization of certain antimicrobials; educational activities; clinical protocols for empirical treatment of infections taking into account local resistances; de-escalation of empirical therapy; dose optimization of antimicrobials; and parental to oral conversion. ${ }^{21}$

The study has some limitations. The use of DDDs has been criticized because it has shown poor correlation with prescribed daily doses in some settings. However, prescribed daily doses may vary among health care facilities and DDDs allow comparison among hospitals or clinics even when prescribed daily doses are different. In addition, this is a single site study of antibiotic consumption in rural India, so our results must be confirmed by studies from other rural sites.

\section{CONCLUSIONS}

The study shows that, in our rural setting, the consumption of antimicrobials in outpatients and inpatients is higher than the ones reported in other countries, but similar to the ones reported in tertiary hospitals and urban areas of India. If these results are confirmed in other sites, the results of this study indicate that there is an urgent need to improve the prescription of antibiotics in rural India.

\section{CONFLICT OF INTEREST}

The authors declare no conflict of interest.

Funding: No funds received.

\section{ELEVADA PRESCRIPCIÓN DE ANTIMICROBIANOS EN UN HOSPITAL RURAL COMARCAL EN INDIA}

RESUMEN

Antecedentes: La Organización Mundial de la Salud (OMS) recomienda la vigilancia del uso de antibióticos como parte de la estrategia de lucha contra la resistencia a antibióticos. Sin embargo, existe poca información del consumo de antibióticos en países en vías de desarrollo, especialmente en áreas rurales.

Objetivos: El objetivo de este estudio fue describir el consumo de antimicrobianos en un hospital rural de India.

Métodos: El estudio se realizó en un hospital comarcal situado en Anantapur, Andhra Pradesh. De acuerdo con las recomendaciones de la OMS, usamos la metodología de la dosis diaria definida (DDD) para medir el uso de antibióticos durante un año (del 1 de agosto de 2011 a 1 de agosto de 2012). El uso de antibióticos se midió usando las DDD/100 ingresos y las DDD/100 pacientesdía para internados y DDD/100 visitas para los externos. Resultados: Durante el periodo de estudio, hubo 15.735 ingresos y 250.611 consultas externas. Se prescribieron antibióticos en el $86 \%$ de los internados y en el $12,5 \%$ de los externos. Las prescripciones de los externos sumaron 
2/3 del consumo total de antibióticos. Para internados, el uso total de antibióticos fue de $222 \mathrm{DDD} / 100$ pacientesdía, de $693 \mathrm{DDD} / 100$ ingresos y el número medio de antibióticos prescritos fue de 1,8. Para los pacientes externos, el uso de antibióticos fue de $86 \mathrm{DDD} / 100$ visitas y la media de antibióticos prescritos fue de 1,2 . Los antibióticos más frecuentemente prescritos fueron las aminopenicilinas y las cefalosporinas de $3^{\mathrm{a}}$ generación para los internados, y las tetraciclinas y quinolonas para los externos. En una muestra de pacientes con diarrea o infecciones del tracto respiratorio superior (URTI), la proporción de pacientes que recibió antibióticos fue del
$84 \%$ (intervalo de confianza [IC] 95\% 67-93) y del 52\% (IC95\% 43-62), respectivamente.

Conclusión: En un entorno rural, el consumo de antibióticos fue extremamente elevado, incluso en situaciones de una etiología predominantemente vírica como diarrea o URTI.

Palabras clave: Antibacterianos; Farmacorresistencia Bacteriana; Utilización de Medicamentos; Prescripción Inadecuada; Salud Rural; India

References

1. WHO. The evolving threat of antimicrobial resistance - Options for action [Internet]. 2012. Available from: http://www.who.int/patientsafety/implementation/amr/publication/en/index.html (accessed April 8, 2014)

2. Ganguly NK, Arora NK, Chandy SJ, Fairoze MN, Gill JP, Gupta U, Hossain S, Joglekar S, Joshi PC, Kakkar M, Kotwan A, Rattan A, Sudarshan H, Thomas K, Wattal C, Easton A, Laxminarayan R; Global Antibiotic Resistance Partnership (GARP) - India Working Group. Rationalizing antibiotic use to limit antibiotic resistance in India. Indian J Med Res. 2011;134:281-294

3. Pathak A, Mahadik K, Dhaneria SP, Sharma A, Eriksson B, Lundborg CS. Antibiotic prescribing in outpatients: Hospital and seasonal variations in Ujjain, India. Scand J Infect Dis. 2011;43(6-7):479-488. doi: 10.3109/00365548.2011.554854

4. Kotwani A, Holloway K, Chaudhury RR. Methodology for surveillance of antimicrobials use among out-patients in Delhi. Indian J Med Res. 2009;129(5):555-560.

5. Kotwani A, Holloway K. Trends in antibiotic use among outpatients in New Delhi, India. BMC Infect Dis. 2011;11:99. doi: 10.1186/1471-2334-11-99

6. S KI, Chandy SJ, Jeyaseelan L, Kumar R, Suresh S. Antimicrobial prescription patterns for common acute infections in some rural \& urban health facilities of India. Indian J Med Res. 2008;128(2):165-171.

7. Office of The Registrar General \& Census Commissioner, India. Census of India. 2011.

8. WHO. The anatomical therapeutic chemical classification system with defined daily doses (ATC/DDD). Oslo URL: http://www who int/classifications/atcddd/en(poslední aktualizace 2003) (accessed April 8, 2014)

9. Bruce J, MacKenzie FM, Cookson B, Mollison J, van der Meer JW, Krcmery V, Gould IM; ARPAC Steering Group. Antibiotic stewardship and consumption: findings from a pan-European hospital study. J Antimicrob Chemother 2009;64(4):853-860. doi: 10.1093/jac/dkp268

10. Zhang W, Shen X, Bergman U, Wang Y, Chen Y, Huang M, Zeng Q, Wei J, Lu Q, Wang G, Deng L, Wang X, Yao K, Yu $\mathrm{S}$, Yang Y. Drug utilisation 90\% (DU90\%) profiles of antibiotics in five Chinese children's hospitals (2002-2006). Int J Antimicrob Agents. 2008;32(3):250-255. doi: 10.1016/j.ijantimicag.2008.04.007

11. Sharma M, Eriksson B, Marrone G, Dhaneria S, Lundborg CS. Antibiotic prescribing in two private sector hospitals; one teaching and one non-teaching: a cross-sectional study in Ujjain, India. BMC Infect Dis. 2012;12:155.

12. Adriaenssens N1, Coenen S, Versporten A, Muller A, Minalu G, Faes C, Vankerckhoven V, Aerts M, Hens N, Molenberghs G, Goossens H; ESAC Project Group. European Surveillance of Antimicrobial Consumption (ESAC): outpatient antibiotic use in Europe (1997-2009). J Antimicrob Chemother. 2011;66(Suppl 6):vi47-vi56. doi: 10.1093/jac/dkr457

13. Norris P, Nguyen HA. Consumption of antibiotics in a small Pacific Island nation: Samoa. Pharm Pract (Granada). 2007;5(1):36-41.

14. Karras DJ, Ong S, Moran GJ, Nakase J, Kuehnert MJ, Jarvis WR, Talan DA; EMERGEncy ID NET Study Group. Antibiotic use for emergency department patients with acute diarrhea: Prescribing practices, patient expectations, and patient satisfaction. Ann Emerg Med. 2003;42(6):835-842.

15. Supcharassaeng S, Suankratay C. Antibiotic prescription for adults with acute diarrhea at King Chulalongkorn Memorial Hospital, Thailand. J Med Assoc Thai. 2011;94(5):545-550.

16. Grijalva CG, Nuorti JP, Griffin MR. Antibiotic prescription rates for acute respiratory tract infections in US ambulatory settings. JAMA. 2009;302(7):758-766. doi: 10.1001/jama.2009.1163

17. Goossens H, Ferech M, Vander Stichele R, Elseviers M. Outpatient antibiotic use in Europe and association with resistance: a cross-national database study. Lancet. 2005;365(9459):579-587.

18. Malhotra-Kumar S, Lammens C, Coenen S, Van Herck K, Goossens H. Effect of azithromycin and clarithromycin therapy on pharyngeal carriage of macrolide-resistant streptococci in healthy volunteers: a randomised, double-blind, placebo-controlled study. Lancet. 2007;369(9560):482-490.

19. Alvarez-Uria, G, Priyadarshini, U, Naik, PK, Midde, M, Reddy, R. Mortality associated with community-acquired cephalosporin-resistant Escherichia coli in patients admitted to a district hospital in a resource-limited setting. Clin Pract. 2012;2(3):e76. doi: 10.4081/cp.2012.e76

20. Alvarez-Uria G, Reddy R. Prevalence and Antibiotic Susceptibility of Community-Associated Methicillin-Resistant Staphylococcus aureus in a Rural Area of India: Is MRSA Replacing Methicillin-Susceptible Staphylococcus aureus in the Community? ISRN Dermatol. 2012;2012:248951. doi: 10.5402/2012/248951

21. Dellit TH, Owens RC, McGowan JE Jr, Gerding DN, Weinstein RA, Burke JP, Huskins WC, Paterson DL, Fishman NO, Carpenter CF, Brennan PJ, Billeter M, Hooton TM; Infectious Diseases Society of America; Society for Healthcare Epidemiology of America. Infectious Diseases Society of America and the Society for Healthcare Epidemiology of America guidelines for developing an institutional program to enhance antimicrobial stewardship. Clin Infect Dis. 2007;44(2):159-177. 